[Regular Paper]

\title{
Oxidative Degradation Behavior of Fatty Acid Methyl Ester in Fish Oil Biodiesel and Improvement of Oxidation Stability by Partial Hydrogenation
}

\author{
Yohko AвE, Makoto ToвA*, Takehisa Mochizuki, and Yuji Yoshimura \\ Research Center for New Fuels and Vehicle Technology, National Institute of Advanced Industrial Science and Technology, \\ 1-1-1 Higashi, Tsukuba, Ibaraki 305-8565, JAPAN
}

(Received November 21, 2008)

\begin{abstract}
Waste cooking oil contaminated with fish oil has potential uses as a biodiesel fuel feedstock. The changes in properties of fish oil fatty acid methyl ester (FAME) caused by oxidation were first evaluated, and the oxidation stability of fish oil FAME was improved by partial hydrogenation using a noble metal catalyst.

Oxidation of fish oil FAME resulted in many decomposition products such as aldehydes, carboxylic acids and ketones, and large amounts of sludge. The oxidation propensity of FAME was proportional to the degree of unsaturation, and polyunsaturated FAMEs with more than 4 double bonds, the main components of fish oil FAME, were almost completely oxidized. Elemental analysis and FT-IR analysis showed that the sludge contained large amounts of oxygen compounds assigned as ketones, esters and carboxylic acids. Gel permeation chromatography (GPC) indicated that the sludge seemed to be formed by polymerization of about ten molecules of FAME, especially polyunsaturated FAME molecules. To improve the oxidation stability of fish oil contaminated biodiesel fuel, partial hydrogenation of fish oil FAME was carried out over Pd-Pt/Yb-USY- $\mathrm{Al}_{2} \mathrm{O}_{3}$ catalyst, with the fish oil FAME mixed with rapeseed oil to simulate the waste cooking oil contaminated with fish oil. Unsaturated FAMEs with more than 2 double bonds were selectively hydrogenated to monounsaturated and saturated FAMEs. Hydrogenated mixed FAME did not form any sludge and the oxidation stability was significantly improved compared with the untreated FAME. The oxidation stability of hydrogenated FAME blended with petroleum diesel was almost equivalent to that of petroleum diesel. Reduction of polyunsaturated FAME by partial hydrogenation is effective for improving the oxidation stability as well as suppression of sludge formation.
\end{abstract}

\section{Keywords}

Biodiesel, Fish oil, Oxidation stability, Sludge, Hydrogenation, Noble metal catalyst

\begin{abstract}
1. 緒言
近年の原油価格高騰や二酸化炭素排出抑制による地球温暖化 対策の観点から, 石油代替燃料として脂肪酸メチルエステル (FAME) が含まれたバイオディーゼル燃料の導入が, 欧州を 中心に積極的に進められている1)。日本においても，2008年2 月にFAMEを軽油に $5 \%$ まで混合することを前提とした $100 \%$ FAME の JIS 規格（JIS K 2390）が制定され，2009年2月に「揮 発油等の品質の確保等に関する法律施行規則 (昭和 52 年省令 第 48 号）の一部を改正した省令 (平成 20 年法律第 48 号) 」2) が 施行されるなど，実用化に向けた準備が整いつつある。

FAME の原料として, 欧州では主として菜種油, 米国では大 豆油, 東南アジア諸国ではパーム油が用いられているが, 植物 油資源にそしい日本では事業所や家庭から排出される廃食用油 の利用例が多( 3) 5)。廃食用油は揚げ物調理の際に食材から融 出した動物油や魚油の混入率が高く, 脂肪酸組成の変動や品質 劣化等に影響を及ぼす ${ }^{6), 7}$ 。特に魚油は, $\mathrm{C}=\mathrm{C}$ 二重結合を 4 個
\end{abstract}

\footnotetext{
* To whom correspondence should be addressed.

* E-mail: m.toba@aist.go.jp
}

以上有する多不飽和脂肪酸の含有量が多いため, 植物油に比べ て著しく酸化されやすく, FAME の酸化劣化による酸や沈殿物 (スラッジ)の生成による燃料タンク内の金属腐食やフィルター の目詰まり等の問題を生じる可能性がある ${ }^{8), 99}$ 。しかし, スラッ ジの生成メカニズムや性状についての詳細は明らかになってい ない。

そこで, 本研究では魚油 FAMEの酸化試験を行い, 生成し た酸化劣化油やスラッジの組成分析から魚油 FAMEに含まれ る多不飽和 FAME の酸化劣化によるスラッジ生成挙動を調べ るとともに, 魚油が混合したバイオディーゼル燃料の酸化安定 性を大幅に改善するため, バイオディーゼル燃料（B100）の 水素化処理による酸化安定性向上を試みた ${ }^{10), 11)}$ 。

\section{2. 実験}

\section{1. 魚油 FAME の調製}

本実験で使用した魚油 FAME は特許記載の方法 ${ }^{12)}$ を用いて 調製した。粗製魚油（日本化学飼料(株)製） $50 \mathrm{~g}$ にテトラヒド ロフラン $22.5 \mathrm{~m} l$ を加え, 混合した後に $0.89 \mathrm{M}(1 \mathrm{M}=1 \mathrm{~mol}$ ・ $\left.\mathrm{dm}^{-3}\right)$ メタノール性水酸化ナトリウム溶液 $14 \mathrm{~m} l$ を添加し, メ タノール還流温度で 4 時間反応させた。反応液を室温まで冷却 
した後, 水 $10 \mathrm{~m} l$ を加えて擋汼して分液ロートに移し，上層を 分取して無水硫酸ナトリウムで乾燥した後シリカゲルカラムに 通し，加熱減圧下で溶媒を留去して魚油 FAMEを得た。

\section{2. 酸化安定性試験}

魚油 FAME の酸化安定性試験は，バイオディーゼル燃料 （B100）の欧州規格（EN 14214）に規定されている Rancimat 試験法（EN 14112）を用いて行った。試験にはRancimat 試験 装置（Metrohm, Rancimat743）を使用し，原料油 $3.0 \mathrm{~g}$ を空気吹 达み量 $10 \mathrm{l} / \mathrm{h}$ の条件下で誘導時間を測定した。FAME 混合軽油 の強制酸化試験は，平成 19 年度経済産業省告示第 81 号 13$)$ に記 載の反応条件 $\left(115^{\circ} \mathrm{C}, 16\right.$ 時間, 酸素吹込み $100 \mathrm{~m} / / \mathrm{min}$ : 以下, 告示法と記す）で行い, 自動電位差滴定装置（Metrohm, Titrando）を用いて強制酸化前後の過酸化物価（基準油脂分析 試験法2.5.2.1-1996 過酸化物価（酢酸-イソオクタン法）準拠） および全酸価（JIS K 2501 準拠）を測定し，それぞれの増加量 を算出して酸化安定性の指標とした。

\section{3. 試料油およびスラッジの分析}

魚油 FAME，菜種油 FAME，魚油 FAME 混合菜種油 FAME, 水素化処理油, FAME 混合軽油の流動点 (ASTM D 6749準拠) および曇り点（ASTM D 2500準拠）は，流動点試験装置（田 中科学機器製作所 (株) 製、MPC-102A）を用いて測定した。 FAMEの組成分析はEN 14103 に規定されているが, 酸化劣化 油中の有機酸や含酸素化合物および魚油に含まれる多不飽和 FAMEの組成分析には適さないため, 魚油FAME およびその 酸化劣化物の組成分析は HP-1 カラムを装填したガスクロマト グラフ／質量分析器 (GC-MS, Agilent 5975, カラム: HP-1, カ ラム寸法: $50 \mathrm{~m} \times 0.2 \mathrm{~mm} \times 0.11 \mu \mathrm{m})$ およびガスクロマトグラフ (GC-FID, Agilent 6890N, カラム: HP-1, カラム寸法: $60 \mathrm{~m} \times$ $0.25 \mathrm{~mm} \times 0.25 \mu \mathrm{m})$ を用いた。また，EN 14103 にる組成分 析は，ネルボン酸メチルとドコサヘキサエン酸メチルのピーク が重なるなど多不飽和 FAME の分離が悪いため, 魚油 FAME, 菜種油 FAME，魚油FAME 混合菜種油FAME およびその水素 化処理油の組成分析には，HP-88カラムを装填したガスクロマ トグラフ (GC-FID, Agilent 6890N, カラム: HP-88, カラム寸法: $100 \mathrm{~m} \times 0.25 \mathrm{~mm} \times 0.2 \mu \mathrm{m})$ を用いた。水分量（JIS K 2275 準拠） は微量水分量測定装置 (三菱化学(株)製, C-200 Moisturemeter) により測定した。

上記試料とスラッジの有機元素定量分析は元素分析計 $(\mathrm{CE}$ Instruments, EA 1110）を用いた。スラッジの平均分子量測定は, $0.05 \mathrm{M}$ 臭化リチウム， $0.02 \mathrm{vol} \%$ リン酸溶液を含有したジメチ ルアセトアミドを加え $80^{\circ} \mathrm{C}$ で加熱溶解し, ゲル浸透クロマト グラフ（Waters, GPC-150C）により解析した。魚油 FAME, 酸化劣化油およびスラッジ中に含まれる官能基分析は, フーリ 工変換赤外分光光度計（Thermo Nicolet, NEXUS670 FT-IR）を 用いて行った。魚油FAME および酸化劣化油については二硫 化炭素に溶解してそれぞれ 10 mass％，2 mass％溶液を調製し， 透過法で測定した。スラッジについては KBrに対して 10 mass\% になるように調製し，拡散反射法により測定した。

\section{4. 魚油 FAME 混合菜種油 FAME の水素化反応}

欧州規格（EN 14214）では，4価以上の多不飽和 FAME 含有 量は $1 \mathrm{mass} \%$ 以下と規定されている。廃食用油は使用する植

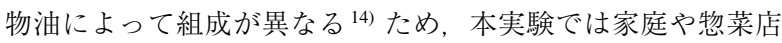

で比較的多く発生する菜種油由来の廃食用油 ${ }^{15)}$ の利用を想定 し, 菜種油FAMEをモデル廃食用油として使用した。魚油が 混入したバイオディーゼル燃料の酸化安定性を検討するため, 4 価以上の多不飽和 FAMEを 1 mass \% 含有するように魚油 FAME6.67 g を菜種油FAME160.0 g に対して混合し, 魚油 FAME 混合菜種油FAME を調製した。この試料油に対してガスクロ マトグラフ（HP-88カラム装填）を用いた組成分析を行ったと ころ, 魚油FAME 混合菜種油 FAME に含まれる4価以上の多 不飽和 FAME は $0.95 \%$ であった（Table 2)。魚油 FAME 混合 菜種油 FAME の部分水素化反応は, $300 \mathrm{~m} l$ ガラス製オートク レーブ（耐圧硝子工業(株)製，ハイパーグラスター TEM-V 型） を用いて, 原料油 $150.0 \mathrm{~g}$ に対して貴金属触媒 $\mathrm{Pd}-\mathrm{Pt} /$ $\mathrm{Yb}-\mathrm{USY}-\mathrm{Al}_{2} \mathrm{O}_{3}$ (粒径 $1000 \sim 1400 \mu \mathrm{m}$ ) $2.0 \mathrm{~g}, 80^{\circ} \mathrm{C}$, 水素圧 $0.5 \mathrm{MPa}$ で所定時間反応を行った。触媒は $300^{\circ} \mathrm{C}$ で 2 時間水素還元して 用いた。

\section{3. 結果および考察}

\section{1. 原料油および酸化劣化油の性状と組成}

魚油FAMEについて, Rancimat 試験前後の物性をそれぞれ 評価した結果を Table 1に示す。魚油 FAMEはEN 14214で定 められた酸化安定性の規格值（6時間以上）を大幅に下回り， 酸化により硬いゴム状のスラッジが大量に析出した。原料油に 対するスラッジ生成量は質量比で約 $24 \%$ を占めることが分 かった。水分量は魚油FAMEでEN 14214の規格值 (500 massppm 以下）を満たしたものの, 酸化劣化油では著しく増加した。こ のことは酸化劣化によって新たに水が生成したことを示してお り, 燃料タンク内腐食の要因となる可能性がある。

魚油 FAME の酸化前後の組成変化を調べるために, GC-MS および GC-FID クロマトグラフ（HP-1 カラム使用）による組 成解析を行った。酸化前後の組成を Table 2 に示す。魚油 FAME の酸化により, 全FAME 含有量は $95.11 \%$ から $64.52 \%$ へと減少した一方で，未同定物質は $4.40 \%$ から $24.34 \%$ と大幅 に増加し, そのうち $18.79 \%$ が炭素数 18 の FAME 検出後の保 持時間 60 分以降に出現したことが明らかとなった。酸化によ る各不飽和 FAME の転化率を Table 2 の FAME 組成から算出し たところ, 4 価以上の不飽和 FAME $(99.4 \%)>3$ 価不飽和 FAME $(92.7 \%)>2$ 価不飽和FAME $(79.4 \%)>1$ 価不飽和 FAME（45.5\%）となり，不飽和度の高いFAME ほど転化率が 高いことが分かった。

異なる不飽和 FAME からどのような酸化劣化物が生成する かを明らかにするため, $\mathrm{C}=\mathrm{C}$ 二重結合が一つのオレイン酸メ チルと $\mathrm{C}=\mathrm{C}$ 二重結合が二つのリノール酸メチル, および $\mathrm{C}=\mathrm{C}$ 二重結合が六つのドコサヘキサエン酸メチルを用いて酸化試験 $\left(115^{\circ} \mathrm{C}\right.$, 酸素吹込み $\left.100 \mathrm{~m} / / \mathrm{min}\right)$ を行った。酸化試験後の GCMS クロマトグラムを Fig. 1に示す（図中のピーク番号は Table 2 に示したピーク番号に同じ)。1時間酸化した場合 (Figs. 1 a, c， e）における主たる反応初期生成物は，オレイ ン酸メチル（a）抽びリノール酸メチル（c）では炭素数 6 11 のアルデヒド $($ No.2, 8, 11, 17, 20, 23, 25, 28, 32, 44), 炭素数 $9 \sim 12$ の $\omega$-オキソカルボン酸メチルエステル (No.49， 57，58，69，70), 炭素数 7〜9の FAME（No.19， 24） 掞よび炭素数 18 のエポキシカルボン酸メチルエステル 
Table 1 Properties of Fresh and Oxidized Fish Oil FAMEs

\begin{tabular}{|c|c|c|c|c|}
\hline & & $\begin{array}{c}\text { Fish oil FAME } \\
\text { before oxidation }\end{array}$ & $\begin{array}{c}\text { Fish oil FAME after } \\
\text { oxidation (supernatant) }\end{array}$ & $\begin{array}{c}\text { Fish oil FAME after } \\
\text { oxidation (sludge) }\end{array}$ \\
\hline \multicolumn{5}{|l|}{ Oxidation stability } \\
\hline Rancimat induction time & {$[\mathrm{h}]$} & 0.49 & n.a. & n.a. \\
\hline Water content & [massppm] & 169.5 & 1829.3 & n.a. \\
\hline \multicolumn{5}{|l|}{ Cold property } \\
\hline Cloud point & {$\left[{ }^{\circ} \mathrm{C}\right]$} & 7 & n.a. & n.a. \\
\hline Pour point & {$\left[{ }^{\circ} \mathrm{C}\right]$} & 0 & n.a. & n.a. \\
\hline \multicolumn{5}{|l|}{ Elemental analysis } \\
\hline Carbon & [mass \%] & 77.6 & 69.8 & 63.4 \\
\hline Hydrogen & [mass \%] & 11.7 & 10.7 & 8.4 \\
\hline Oxygen & [mass\%] & 10.6 & 19.4 & 28.2 \\
\hline Nitrogen & [mass\%] & n.d. & n.d. & n.d. \\
\hline Sulfur & [mass\%] & n.d. & n.d. & n.d. \\
\hline Hydrogen/Carbon & [atomic ratio] & 1.80 & 1.83 & 1.57 \\
\hline Oxygen/Carbon & [atomic ratio] & 0.10 & 0.21 & 0.33 \\
\hline
\end{tabular}

n.a.: not analyzed. n.d.: not detected.

（No.110，113）であり，スラッジの生成は見られなかった。一 方, ドコサヘキサエン酸メチル（e）では炭素数7のアルデヒ ド（No.14）と炭素数 12〜18の FAME（No.60，74，84, 86, 96，98）のほか, 構造不明の低分子量物質が多種類生成し, 少 量のスラッジ析出も見られた。強制規格の試験時間と同じ反応 時間 16 時間後では, ドコサヘキサエン酸メチルはその全てが 硬いゴム状のスラッジへと変化したため GC-MSによる成分分 析ができなかった。

オレイン酸メチル (Fig. 1 b) およびリノール酸メチル (Fig. 1 d）は, 酸化試験 1 時間後に得られたアルデヒドや $\omega$-オキソカ ルボン酸メチルエステルがこれらに対応するカルボン酸 (No. $1 ， 7 ， 15 ， 26 ， 29 ， 36 ， 45)$ やジカルボン酸モノメチルエステ ル（No.46，54，64）に酸化された。酸素酸化においては, $\mathrm{C}=\mathrm{C}$ 二重結合に隣接した炭素上の水素を引き抜いて過酸化物 ラジカルが生成されるとされ ${ }^{16)}$ ，モデル反応で見られた低分子 量酸化劣化物は, これら過酸化物ラジカルが分解して生成する と想定される酸化劣化物と一致した。一方, エポキシカルボン 酸メチルエステルは16時間後には減少（b）または消失（d）し, より保持時間の長い構造不明な高分子量物質が多種類新たに生 成した。

これらの高分子量物質はオレイン酸メチルの場合は反応時間 1 時間ではほとんど生成していないのに対し，リノール酸メチ ルでは反応時間 1 時間でも生成が見られることから, 不飽和度 が高いFAMEはより容易に高分子量物質を生成しやすいこと が分かった。以上の結果から，スラッジの燃料ポンプ内での付 着やフィルターの目詰まり等のトラブルを低減するには, 多不 飽和 FAME の除去処理が有効であると考えられる。

\section{2. 魚油 FAME スラッジの組成および構造}

酸化試験前後の各試料油㧍よびスラッジに対して炭素, 水素, 酸素, 窒素および硫黄の元素分析を行った。各試料の元素組成 を Table 1 に示す。酸化劣化油およびスラッジの酸素／炭素原 子比は, 魚油FAMEと比較していずれも増加した。魚油 FAME の酸化によって含酸素化合物量が増大したことが主な要 因であると考えられる。酸素／炭素原子比はスラッジの方が酸 化劣化油の上澄み液よりも 0.11 大きいことから, スラッジはよ
り酸化劣化が進んだ含酸素化合物で構成されていることが分 かった。一方, 水素/炭素原子比は, 酸化劣化油中ではわずか に増加したのに対し，スラッジでは減少した。酸化劣化油では 原料油に見られなかった多不飽和 FAMEが新たに生成してお り（Table 2, ピーク No.105, 106), 脱水素反応や水素のシフ トによる異性化が起きている可能性がある。また, Table 1 に 示した水分量の増加は, この脱水素反応によって生じた水素と 酸素が反応したためであると考えられる。スラッジは酸素付加 による酸化や脱水素による不飽和化合物の生成により生じた物 質が重合して生成したものと推測されたが, 水素/炭素原子比 が 1.57 と低く水素の減少が見られたことから，ここでも水を生 じた可能性が考えられ，スラッジの生成にも水分量の増加を伴 うことが示唆された。

スラッジをジメチルアセトアミドに溶解し, ゲル浸透クロマ トグラフにより平均分子量を求めたところ, 数平均分子量 $(M n)$ は3150であった。スラッジは魚油 FAME 中の不飽和 FAME の 酸化によって生成すると仮定した場合, Table 2 に示した含有 量 $1 \%$ 以上の不飽和 FAMEの分子量から算出した原料油の平 均分子量は $M=314$ となり, この数值と $M n$ を用いてスラッジ の重合度の換算を行ったところ, 10 量体程度のポリマーを形 成していることが分かった。また，スラッジの分子量分布は約 600 から 20,000,000 と, 非常に幅広い分子量分布を持つことが 確認された。

各試料についての分子構造をより明らかにするため, FT-IR による官能基分析を行った。各試料のスペクトルを Fig. 2 に示 す。魚油FAME（a）では $3010 \mathrm{~cm}^{-1}$ にアルケンの C-H 伸縮振 動（ピークNo.2）, $714 \mathrm{~cm}^{-1}$ にアルケンの面外変角振動（ピー クNo.14）による吸収帯がそれぞれ見られたが, 酸化試験後の 生成油（b）では消失したことからアルケンの $\mathrm{C}=\mathrm{C}$ 二重結合が 酸化によって開裂したことが確認された。スラッジのIR スペ クトル $(\mathbf{c})$ では全体にピークはブロードとなった。これは種々 の官能基を持った高分子化合物を含有しているためと考えられ る。スラッジのIR スペクトルには， $3700 〜 3100 \mathrm{~cm}^{-1}$ おううひ $2800 \sim 2400 \mathrm{~cm}^{-1}$ に O-H 伸縮振動（ピーク No.1，5）の吸収帯 が現れた。この吸収は魚油 FAME や酸化劣化油の上澄み部分 
Table 2 Composition of Fresh and Oxidized Fish Oil FAMEs

\begin{tabular}{|c|c|c|c|c|c|c|c|c|c|}
\hline $\begin{array}{l}\text { Peak } \\
\text { No. }\end{array}$ & $\begin{array}{c}\text { R.T } \\
{[\mathrm{min}]}\end{array}$ & Compounds & $\begin{array}{c}\text { Fresh } \\
{[\operatorname{area} \%]}\end{array}$ & $\begin{array}{c}\text { Oxidized } \\
\text { product } \\
{[\text { area } \%]}\end{array}$ & $\begin{array}{l}\text { Peak } \\
\text { No. }\end{array}$ & $\begin{array}{c}\text { R.T } \\
\text { [min] }\end{array}$ & Compounds & $\begin{array}{c}\text { Fresh } \\
{[\operatorname{area} \%]}\end{array}$ & $\begin{array}{c}\text { Oxidized } \\
\text { product } \\
\text { [area } \%]\end{array}$ \\
\hline 1 & - & Butyric acid $^{\text {a) }}$ & - & - & & 39.16 & Unknown & 0.17 & 0.19 \\
\hline \multirow[t]{2}{*}{2} & 8.52 & Hexanal $^{\text {a) }}$ & 0.20 & 0.39 & 66 & 39.46 & Methyl tridecanoate & 0.03 & 0.03 \\
\hline & 8.85 & Unknown & - & 0.06 & & 40.67 & Unknown & - & 0.04 \\
\hline 3 & 9.38 & Octane $^{a)}$ & 0.01 & 0.04 & 67 & 40.77 & Tridecanoic acid & - & 0.05 \\
\hline 4 & 9.59 & Methyl valerate & - & 0.01 & & 40.96 & Unknown & - & 0.14 \\
\hline 5 & 10.33 & 1-Hexanol & 0.01 & 0.02 & & 41.49 & Unknown & - & 0.11 \\
\hline 6 & - & 2-Heptanone ${ }^{\text {a) }}$ & - & - & & 42.18 & Unknown & 0.02 & 0.02 \\
\hline 7 & - & Valeric acid ${ }^{\text {a) }}$ & - & - & 68 & 42.52 & 2-Pentadecanone & 0.01 & 0.07 \\
\hline \multirow[t]{2}{*}{8} & 11.26 & Heptanal $^{\text {a) }}$ & 0.06 & 0.12 & 69 & - & Methyl 11-oxo-9-undecenoate ${ }^{a)}$ & - & - \\
\hline & 11.36 & Unknown & - & 0.06 & 70 & - & Methyl 12-oxo-9-dodecenoate ${ }^{\text {a) }}$ & - & - \\
\hline 9 & 11.71 & Nonane & - & 0.05 & 71 & 42.68 & Methyl tetradecenoate & 0.03 & 0.05 \\
\hline 10 & 12.14 & Methyl caproate & 0.78 & 1.30 & & 42.88 & Unknown & 0.01 & 0.01 \\
\hline 11 & - & 2-Heptenal ${ }^{\text {a) }}$ & - & - & 72 & 43.04 & Methyl tetradecenoate & 0.07 & 0.03 \\
\hline 12 & - & 1-Heptanol ${ }^{\mathrm{a})}$ & - & - & 73 & 43.36 & Heptadecane & 0.01 & 0.04 \\
\hline 13 & - & $1-$ Octene $^{\text {a) }}$ & - & - & 74 & 43.67 & Methyl myristate $^{a)}$ & 3.08 & 2.51 \\
\hline 14 & - & 2,4-Heptadienal ${ }^{\text {a) }}$ & - & - & & 43.81 & Unknown & 0.06 & 0.08 \\
\hline 15 & - & 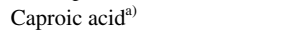 & - & - & 75 & 45.02 & Methyl 6-(5-oxotetrahydro-2- & - & 0.15 \\
\hline 16 & 14.78 & Methyl 5-oxopentanoate & - & 0.02 & & & furyl)hexanoate & & \\
\hline 17 & 15.04 & Octanal $^{\text {a) }}$ & - & 0.07 & 76 & 45.20 & Myristic acid & - & 0.04 \\
\hline 18 & 15.64 & Decane & - & 0.02 & & 45.36 & Unknown & 0.02 & 0.01 \\
\hline 19 & 15.85 & Methyl enanthate ${ }^{a)}$ & - & 0.04 & & 45.72 & Unknown & - & 0.05 \\
\hline 20 & 16.82 & 2-Octenal ${ }^{\text {a) }}$ & - & 0.01 & 77 & 45.83 & Methyl 4,8,12-trimethyltridecanoate & 0.06 & 0.07 \\
\hline 21 & 17.37 & $1-$ Octanol $^{\text {a) }}$ & - & 0.02 & & 46.25 & Unknown & 0.12 & 0.15 \\
\hline 22 & - & Methyl 5-oxohexanoate ${ }^{a)}$ & - & - & 78 & 46.56 & Methyl 12-methyltetradecanoate & 0.05 & 0.08 \\
\hline 23 & 18.46 & Nonanal $^{\mathrm{a})}$ & - & 0.17 & & 46.88 & Unknown & 0.02 & 0.03 \\
\hline 24 & 19.20 & Methyl caprylate ${ }^{\text {a) }}$ & - & 0.04 & 79 & 47.64 & Methyl pentadecanoate & 0.48 & 0.66 \\
\hline 25 & 20.22 & 2-Nonenal ${ }^{\text {a) }}$ & - & 0.02 & & 48.87 & Unknown & - & 0.04 \\
\hline \multirow[t]{4}{*}{26} & - & Enanthic acid ${ }^{\text {a) }}$ & - & - & & 49.10 & Unknown & - & 0.04 \\
\hline & 20.56 & Unknown & - & 0.09 & & 49.45 & Unknown & 0.01 & 0.06 \\
\hline & 20.79 & Unknown & - & 0.02 & 80 & 49.60 & Methyl hexadecatetraenoate & 0.18 & - \\
\hline & 21.40 & Unknown & - & 0.02 & & 49.71 & Unknown & - & 0.07 \\
\hline 27 & - & Methyl 6-oxoheptanoate $e^{a)}$ & - & - & 81 & 49.94 & Methyl hexadecatrienoate & 0.17 & 0.08 \\
\hline \multirow[t]{2}{*}{28} & 21.83 & Decanal $^{\text {a) }}$ & - & 0.05 & 82 & 50.08 & Methyl 14-methylpentadecanoate & - & 0.14 \\
\hline & 21.88 & Unknown & - & 0.06 & & 50.09 & Unknown & 0.10 & - \\
\hline 29 & - & Caprylic acid $^{\text {a) }}$ & - & - & 83 & 50.39 & Methyl hexadecenoate & 0.23 & 0.14 \\
\hline 30 & - & Methyl nonenoate ${ }^{\text {a) }}$ & - & - & 84 & 50.57 & Methyl palmitoleate $^{\text {a) }}$ & 5.00 & 2.14 \\
\hline 31 & 22.52 & Methyl pelargonate & - & 0.03 & & 50.70 & Unknown & - & 0.10 \\
\hline 32 & 23.72 & 2-Decenal ${ }^{\text {a) }}$ & - & 0.05 & 85 & 50.90 & Methyl hexadecenoate & 0.16 & 0.09 \\
\hline 33 & - & Methyl 7-oxooctanoate ${ }^{a)}$ & - & - & & 51.10 & Unknown & 0.03 & 0.06 \\
\hline 34 & - & 2,4-Decadienal ${ }^{\text {a) }}$ & - & - & 86 & 51.47 & Methyl palmitate ${ }^{a)}$ & 13.82 & 24.44 \\
\hline 35 & - & 2,4-Decadienal ${ }^{\text {a }}$ & - & - & & 51.69 & Unknown & 0.03 & - \\
\hline 36 & 23.89 & Pelargonic acid ${ }^{\text {a) }}$ & - & 0.17 & & 51.99 & Unknown & 0.01 & 0.05 \\
\hline 37 & 24.12 & Monomethyl adipate ${ }^{\text {a) }}$ & - & 0.05 & 87 & 52.47 & Palmitic acid & 0.17 & 0.18 \\
\hline 38 & 24.49 & 2-Undecanone & - & 0.04 & 88 & 52.58 & Methyl hexadecadienoate & - & 0.04 \\
\hline 39 & 25.59 & Undecanal & - & 0.07 & & 52.77 & Unknown & 0.02 & 0.02 \\
\hline 40 & 25.73 & Methyl 8-oxooctanoate ${ }^{\text {a) }}$ & - & 0.15 & & 53.04 & Unknown & 0.04 & - \\
\hline 41 & - & Methyl 4-oxooctanoate ${ }^{\text {a) }}$ & - & - & & 53.22 & Unknown & 0.05 & 0.08 \\
\hline 42 & 26.35 & Methyl capriate & - & 0.03 & 89 & 53.33 & Methyl 7-methyl-6-hexadecenoate & 0.74 & 0.06 \\
\hline 43 & 27.03 & $\gamma$-Nonanolactone & - & 0.02 & & 53.53 & Unknown & 0.04 & 0.11 \\
\hline 44 & 27.85 & 2-Undecenal ${ }^{\text {a) }}$ & - & 0.16 & 90 & 53.73 & Methyl 15-methylhexadecanoate & 0.16 & 0.30 \\
\hline 45 & 28.06 & Capric acid ${ }^{\text {a) }}$ & - & 0.10 & & 53.92 & Unknown & 0.03 & 0.01 \\
\hline 46 & 28.70 & Monomethyl pimelate ${ }^{\text {a) }}$ & - & 0.06 & 91 & 54.08 & Methyl 14-methylhexadecanoate & 0.59 & 0.46 \\
\hline 47 & 29.30 & Methyl 8-oxononanoate ${ }^{\text {a) }}$ & - & 0.03 & & 54.22 & Unknown & 0.05 & 0.04 \\
\hline 48 & 29.43 & Dodecanal & - & 0.02 & & 54.33 & Unknown & 0.02 & 0.09 \\
\hline 49 & 30.13 & Methyl 9-oxononanoate ${ }^{\text {a) }}$ & - & 0.22 & & 54.44 & Unknown & 0.05 & - \\
\hline 50 & 30.68 & Methyl undecanoate & - & 0.02 & 92 & 54.74 & Methyl 8-(2-hexylcyclopropyl)-octanoate & 0.05 & 0.04 \\
\hline 51 & 31.62 & $\gamma$-Decanolactone & - & 0.02 & 93 & 54.99 & Methyl heptadecanoate & 0.48 & 0.97 \\
\hline 52 & 31.79 & 2-Dodecenal & - & 0.02 & 94 & 55.54 & Methyl 2-hydroxyhexadecanoate & - & 0.08 \\
\hline 53 & 32.13 & Undecanoic acid & - & 0.13 & & 56.05 & Unknown & 0.01 & 0.04 \\
\hline 54 & 32.36 & Monomethyl suberate $\mathrm{e}^{\mathrm{a})}$ & - & 0.31 & & 56.17 & Unknown & 0.24 & 0.17 \\
\hline 55 & 33.97 & Methyl 9-oxodecanoate ${ }^{\text {a) }}$ & - & 0.05 & & 56.32 & Unknown & - & 1.28 \\
\hline 56 & 34.43 & Tridecanal & - & 0.02 & & 56.36 & Unknown & 0.03 & - \\
\hline 57 & 34.66 & Methyl 10-oxodecanoate ${ }^{a)}$ & - & 0.11 & & 56.55 & Unknown & 0.11 & - \\
\hline 58 & - & Methyl 10-oxo-8-decenoate ${ }^{\text {a) }}$ & - & - & & 56.64 & Unknown & - & 0.06 \\
\hline 59 & 34.80 & Pentadecane & - & 0.02 & & 56.69 & Unknown & 1.27 & - \\
\hline 60 & 35.09 & Methyl laurate ${ }^{a)}$ & - & 0.03 & & 56.78 & Unknown & - & 0.63 \\
\hline 61 & 35.69 & $\gamma$-Undecanolactone & - & 0.02 & & 56.89 & Unknown & 0.07 & - \\
\hline 62 & 36.29 & 2-Tridecenal & - & 0.02 & 95 & 57.00 & Methyl 15-methylheptadecanoate & - & 0.99 \\
\hline 63 & 36.50 & Lauric acid & - & 0.04 & & 57.02 & Unknown & 0.21 & - \\
\hline \multirow[t]{4}{*}{64} & 36.76 & Monomethyl azelate ${ }^{a)}$ & - & 0.43 & 96 & 57.17 & Methyl linoleate $\mathrm{e}^{\mathrm{a})}$ & 2.31 & 0.28 \\
\hline & 36.88 & Unknown & 0.02 & 0.09 & 97 & 57.30 & Methyl linolenate & 0.70 & - \\
\hline & 37.05 & Unknown & - & 0.13 & 98 & 57.52 & Methyl oleate $\mathrm{e}^{\mathrm{a})}$ & 16.95 & 8.57 \\
\hline & 37.62 & Unknown & 0.01 & 0.05 & 99 & 57.66 & Methyl octadecenoate ${ }^{\text {a) }}$ & 3.26 & 1.99 \\
\hline 65 & 38.43 & Methyl 8(2-furyl)octanoate & - & 0.03 & 100 & 57.70 & Methyl octadecenoate & - & 0.51 \\
\hline
\end{tabular}

a) Compounds correspond to the peak number of oxidative decomposition products in Fig. 1. 
(continued from previous page)

\begin{tabular}{|c|c|c|c|c|c|c|c|c|c|}
\hline $\begin{array}{l}\text { Peak } \\
\text { No. }\end{array}$ & $\begin{array}{c}\text { R.T } \\
{[\mathrm{min}]}\end{array}$ & Compounds & $\begin{array}{c}\text { Fresh } \\
{[\operatorname{area} \%]}\end{array}$ & $\begin{array}{c}\text { Oxidized } \\
\text { product } \\
{[\text { area } \%]}\end{array}$ & $\begin{array}{l}\text { Peak } \\
\text { No. }\end{array}$ & $\begin{array}{c}\text { R.T } \\
{[\mathrm{min}]}\end{array}$ & Compounds & $\begin{array}{c}\text { Fresh } \\
{[\operatorname{area} \%]}\end{array}$ & $\begin{array}{c}\text { Oxidized } \\
\text { product } \\
\text { [area \%] }\end{array}$ \\
\hline 101 & 57.87 & Methyl octadecenoate & - & 0.12 & & 69.18 & Unknown & 0.26 & - \\
\hline 102 & 57.95 & Methyl octadecenoate & - & 0.23 & & 69.33 & Unknown & - & 0.92 \\
\hline \multirow[t]{2}{*}{103} & 58.10 & Methyl octadecenoate & - & 0.17 & & 69.46 & Unknown & 0.13 & - \\
\hline & 58.18 & Unknown & 0.04 & - & & 69.48 & Unknown & - & 0.49 \\
\hline \multirow[t]{9}{*}{104} & 58.40 & Methyl stearate & 3.67 & 7.30 & 129 & 69.76 & Methyl erucate & 5.49 & 2.73 \\
\hline & 58.48 & Unknown & - & 0.30 & 130 & 69.86 & Methyl docosenoate & 0.86 & 0.58 \\
\hline & 58.63 & Unknown & 0.24 & 0.24 & 131 & 70.05 & Methyl docosenoate & 0.27 & 0.15 \\
\hline & 58.76 & Unknown & - & 0.07 & & 70.19 & Unknown & - & 0.06 \\
\hline & 58.91 & Unknown & 0.05 & 0.01 & & 70.35 & Unknown & 0.04 & 0.05 \\
\hline & 59.18 & Unknown & 0.02 & - & 132 & 70.61 & Methyl behenate & 0.15 & 0.32 \\
\hline & 59.33 & Unknown & 0.09 & 0.05 & & 70.86 & Unknown & - & 0.88 \\
\hline & 59.43 & Unknown & 0.05 & 0.05 & & 70.94 & Unknown & 0.01 & - \\
\hline & 59.52 & Unknown & 0.03 & 0.04 & & 71.39 & Unknown & - & 0.07 \\
\hline \multirow[t]{2}{*}{105} & 59.67 & Methyl octadecadienoate & - & 0.12 & & 72.01 & Unknown & 0.01 & 0.15 \\
\hline & 59.79 & Unknown & 0.05 & - & & 72.41 & Unknown & 0.01 & 0.19 \\
\hline \multirow[t]{11}{*}{106} & 59.83 & Methyl octadecadienoate & - & 0.09 & & 72.53 & Unknown & 0.03 & - \\
\hline & 60.06 & Unknown & 0.07 & 0.32 & & 72.69 & Unknown & 0.05 & 0.04 \\
\hline & 60.30 & Unknown & - & 0.18 & & 72.78 & Unknown & 0.03 & 0.08 \\
\hline & 60.48 & Unknown & 0.02 & 0.09 & & 73.01 & Unknown & - & 0.09 \\
\hline & 60.57 & Unknown & 0.05 & - & 133 & 73.40 & Methyl tricosanoate & 0.05 & 0.11 \\
\hline & 60.69 & Unknown & 0.10 & 0.06 & & 73.73 & Unknown & 0.08 & - \\
\hline & 60.82 & Unknown & 0.13 & 0.15 & & 73.82 & Unknown & - & 0.06 \\
\hline & 60.90 & Unknown & 0.02 & - & & 74.21 & Unknown & 0.09 & - \\
\hline & 61.04 & Unknown & 0.02 & 0.04 & & 74.35 & Unknown & - & 0.13 \\
\hline & 61.19 & Unknown & 0.03 & 0.03 & & 74.62 & Unknown & - & 1.76 \\
\hline & 61.45 & Unknown & 0.02 & 0.05 & & 75.00 & Unknown & - & 1.15 \\
\hline \multirow[t]{5}{*}{107} & 61.63 & Methyl nonadecanoate & 0.14 & 0.35 & & 75.18 & Unknown & - & 0.23 \\
\hline & 61.76 & Unknown & - & 0.09 & 134 & 75.29 & Methyl tetracosenoate & 0.20 & 0.10 \\
\hline & 62.11 & Unknown & - & 0.10 & 135 & 75.44 & Methyl nervonate & 0.85 & 0.70 \\
\hline & 62.26 & Unknown & - & 0.03 & 136 & 75.62 & Methyl tetracosenoate & 0.07 & - \\
\hline & 62.36 & Unknown & - & 0.07 & & 75.79 & Unknown & - & 0.07 \\
\hline 108 & 62.43 & Methyl eicosapentaenoate & 1.17 & - & 137 & 76.12 & Methyl lignocerate & 0.10 & 0.20 \\
\hline \multirow[t]{2}{*}{109} & 62.58 & Methyl eicosapentaenoate (EPA) & 5.83 & 0.05 & & 76.43 & Unknown & - & 0.74 \\
\hline & 62.67 & Unknown & - & 0.36 & & 76.62 & Unknown & - & 0.06 \\
\hline 110 & 62.90 & Methyl 9,10-epoxy-octadecanoate ${ }^{\text {a) }}$ & - & 5.26 & & 77.34 & Unknown & - & 0.05 \\
\hline 111 & 63.02 & Methyl eicosatrienoate & 0.22 & - & & 77.57 & Unknown & - & 0.05 \\
\hline 112 & 63.16 & Methyl eicosatetraenoate & 0.67 & - & & 77.98 & Unknown & - & 0.11 \\
\hline \multirow[t]{4}{*}{113} & 63.30 & Methyl 9,10-epoxy-octadecanoate ${ }^{\text {a) }}$ & - & 2.11 & & 78.50 & Unknown & - & 0.12 \\
\hline & 63.28 & Unknown & 0.14 & - & 138 & 78.83 & Methyl cerotate & 0.04 & 0.02 \\
\hline & 63.47 & Unknown & - & 2.15 & 139 & 80.02 & 3,5-Cholestadien-7-one & - & 0.31 \\
\hline & 63.52 & Unknown & 0.05 & - & & 80.43 & Unknown & - & 0.26 \\
\hline 114 & 63.66 & Methyl eicosadienoate & 0.31 & - & & 80.65 & Unknown & 0.01 & 0.09 \\
\hline 115 & 63.82 & Methyl eicosenoate & 3.64 & 1.77 & & 80.78 & Unknown & 0.06 & 0.16 \\
\hline 116 & 63.91 & Methyl eicosenoate & 2.95 & 1.52 & & 80.92 & Unknown & - & 0.12 \\
\hline 117 & 64.09 & Methyl eicosenoate & 0.41 & 0.31 & & 81.40 & Unknown & 0.05 & 0.04 \\
\hline 118 & 64.20 & Methyl eicosenoate & - & 0.32 & & 81.85 & Unknown & - & 0.14 \\
\hline & 64.40 & Unknown & 0.08 & 0.10 & & 85.65 & Unknown & - & 0.09 \\
\hline & 64.61 & Unknown & - & 0.09 & & 86.86 & Unknown & - & 0.04 \\
\hline 119 & 64.73 & Methyl arachidate & 0.27 & 0.63 & & 87.18 & Unknown & 0.05 & - \\
\hline & 64.90 & Unknown & - & 2.46 & & 87.42 & Unknown & 0.06 & - \\
\hline & 65.34 & Unknown & 0.01 & 0.06 & & 90.24 & Unknown & - & 0.20 \\
\hline 120 & 65.66 & Ethyl eicosapentaenoate & 0.27 & - & & & & & \\
\hline & 65.74 & Unknown & - & 0.28 & & Composi & ition & & \\
\hline & 65.90 & Unknown & 0.02 & 0.06 & & & FAME & & \\
\hline & 66.00 & Unknown & - & 0.09 & & & Saturated FAME & 23.19 & 39.14 \\
\hline & 66.34 & Unknown & 0.01 & 0.19 & & & Unsaturated FAME: 1 & 40.78 & 22.23 \\
\hline & 66.57 & Unknown & 0.01 & 0.45 & & & Unsaturated FAME: 2 & 2.62 & 0.54 \\
\hline 121 & 66.74 & Methyl 10-(2-octylcycropropyl)-decanoate & 0.29 & - & & & Unsaturated FAME: 3 & 1.09 & 0.08 \\
\hline & 66.82 & Unknown & 0.06 & - & & & Unsaturated FAME: $\geqq 4$ & 25.47 & 0.15 \\
\hline & 67.01 & Unknown & - & 0.23 & & & Branched FAME & 1.96 & 2.14 \\
\hline & 67.03 & Unknown & 0.03 & - & & & Pentacyclic FAME & - & 0.24 \\
\hline & 67.15 & Unknown & - & 0.30 & & & Total & 95.11 & 64.52 \\
\hline 122 & 67.74 & Methyl heneicosanoate & 0.06 & 0.10 & & & Compounds except for FAME & & \\
\hline & 67.93 & Unknown & - & 0.05 & & & Acid & 0.17 & 8.93 \\
\hline 123 & 67.99 & Methyl docosahexaenoate ${ }^{\text {a) }}$ & 0.59 & 0.08 & & & Ketone & 0.01 & 0.11 \\
\hline 124 & 68.17 & Methyl docosahexaenoate (DHA) ${ }^{\text {a) }}$ & 12.65 & - & & & Ketoester & - & 0.08 \\
\hline 125 & 68.43 & Methyl docosatetraenoate & 0.70 & 0.02 & & & Aldehyde & 0.26 & 1.19 \\
\hline & 68.69 & Unknown & - & 0.11 & & & $\omega$-Methyl oxocarboxylate & - & 0.50 \\
\hline 126 & 68.58 & Methyl docosapentaenoate & 2.41 & - & & & Alcohol & 0.01 & 0.19 \\
\hline 127 & 68.78 & Methyl 9,10-dihydroxyoctadecanoate & - & 0.06 & & & Hydrocarbon & 0.04 & 0.13 \\
\hline & 68.97 & Unknown & - & 1.91 & & & Total & 0.49 & 11.13 \\
\hline 128 & 68.96 & $\begin{array}{l}\text { Methyl 11-(3,4-dimethyl-5-pentyl-2- } \\
\text { furyl)undecanoate }\end{array}$ & 0.29 & - & & & Jnknown & 4.40 & 24.34 \\
\hline & 69.09 & Unknown & 0.12 & - & & & & & \\
\hline
\end{tabular}

a) Compounds correspond to the peak number of oxidative decomposition products in Fig. 1. 

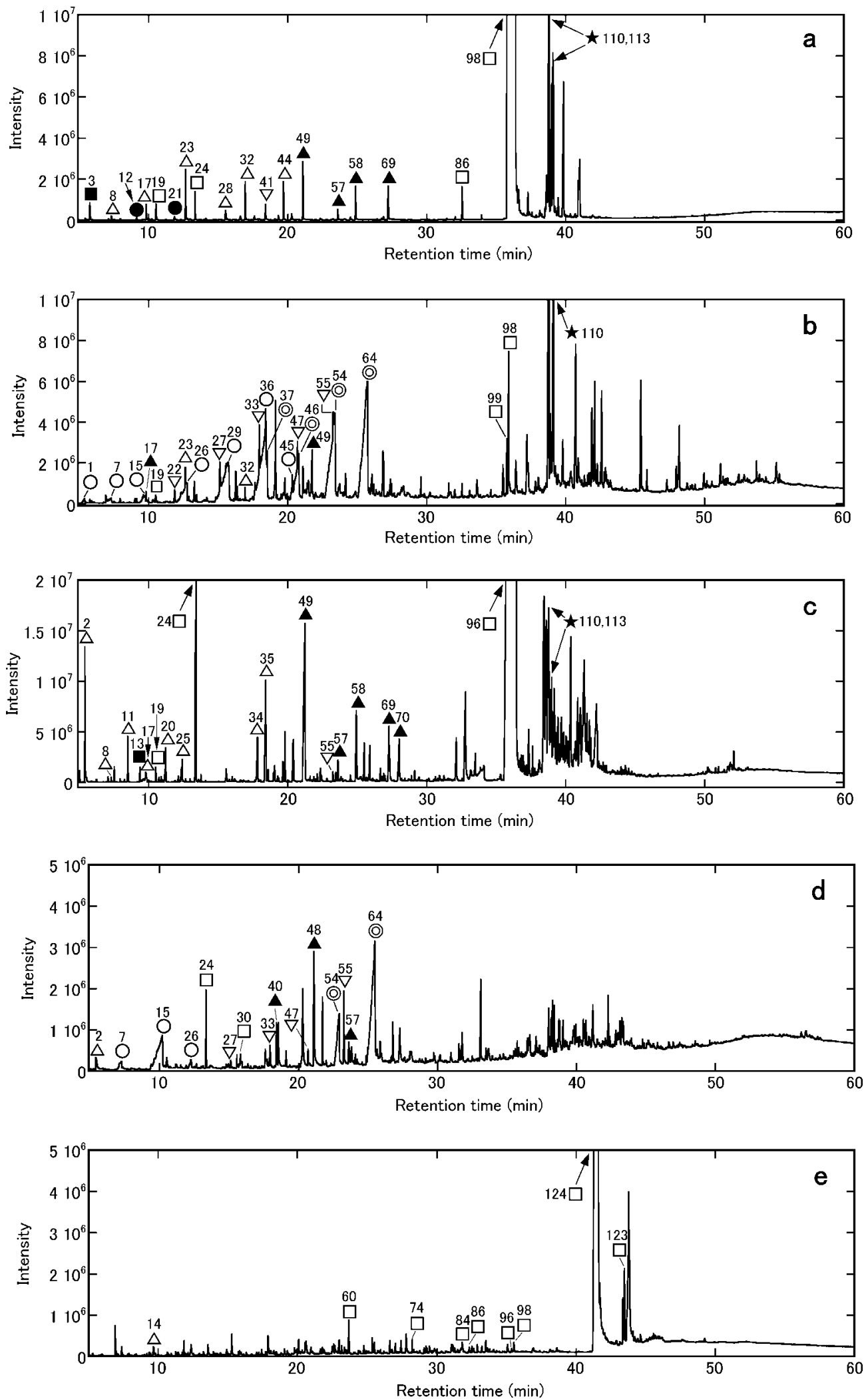

a: Methyl oleate ( $1 \mathrm{~h}$ oxidation), b: Methyl oleate ( $16 \mathrm{~h}$ oxidation), c: Methyl linoleate ( $1 \mathrm{~h}$ oxidation), d: Methyl linoleate (16 h oxidation), e: Methyl docosahexaenoate (1 h oxidation)

$\square$ : FAME, $\square$ : Hydrocarbon, $\bigcirc$ : Alcohol, $\nabla$ : Ketoester, $\triangle$ : Aldehyde, $\mathbf{\Delta}: \omega$-Methyl oxocarboxylate, $\bigcirc$ : Acid, $\bigcirc$ : Monomethyl dicarboxylate, $\star$ : Methyl epoxycarboxylate.

Fig. 1 Oxidative Decomposition Products of Methyl Oleate, Methyl Linoleate and Methyl Docosahexaenoate (R.T: 5.0-60.0 min) 

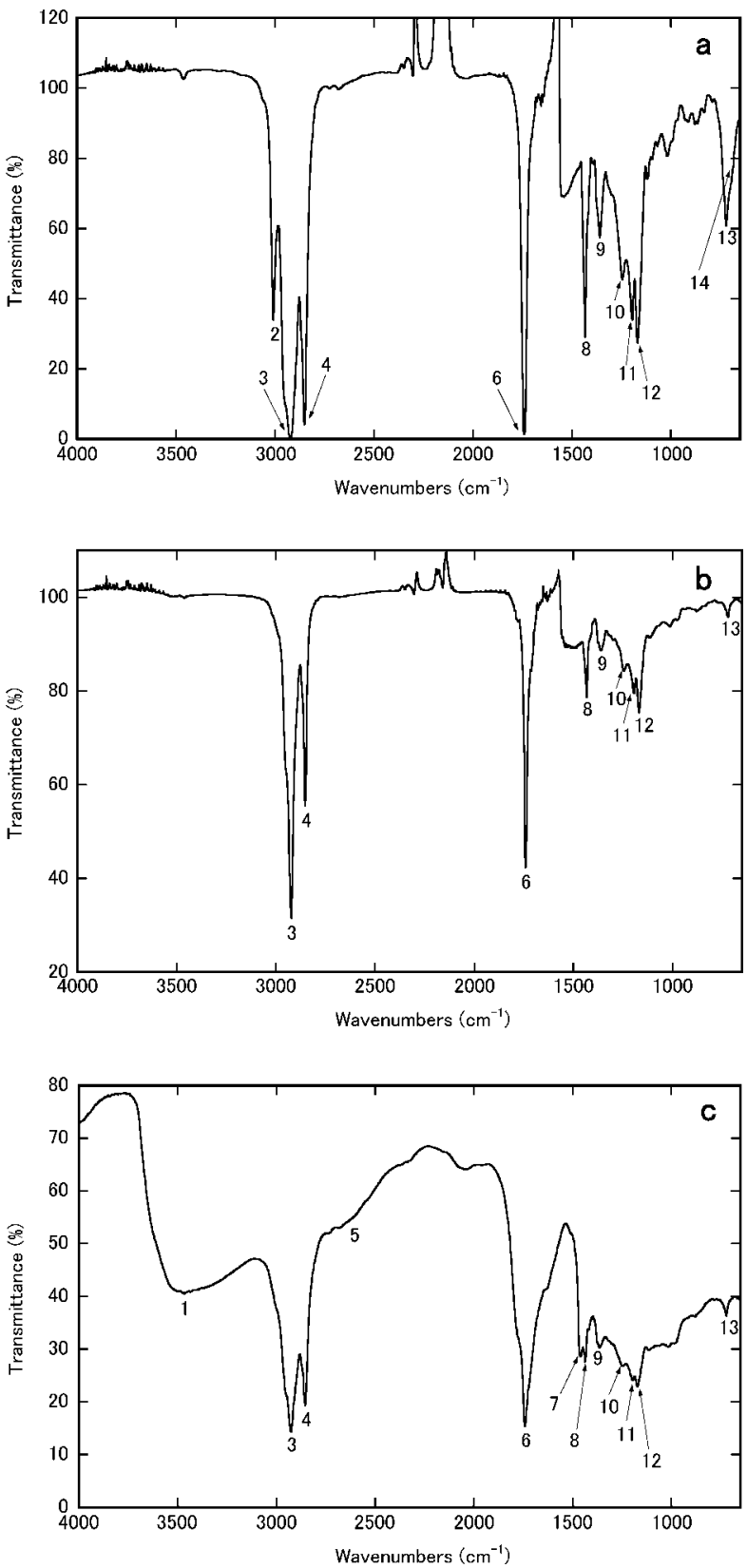

a: Before oxidation, b: After oxidation, c: Sludge.

Fig. 2 IR Spectra of Various Fish Oil FAMEs

の油にはほとんど見られなかったが, カルボン酸ないしアル コールの水酸基によるものと考えられる。以上の結果から，魚 油 FAME の酸化により不飽和 FAME に含まれる $\mathrm{C}=\mathrm{C}$ 二重結合 の多くは消失し，一部は Table 2 に示すアルデヒド（ピーク No.2）やカルボン酸類（ピークNo.54）など，モデル反応で見 られた比較的低分子量の酸化生成物として酸化劣化油に残存す るものの, 残りの大部分は重合により高次元架橋構造を有する スラッジを形成することが示唆された。

\section{3. 魚油 FAME 混合菜種油 FAME の水素化による酸化安 定性向上}

酸化劣化試験と劣化生成物の組成分析から, 酸化劣化物の生
成は多不飽和 FAMEの開裂によるアルデヒド類やカルボン酸 などの低分子化合物の生成と酸化や脱水素により引き起こされ る重合物生成が主たる原因であることが推察された。したがっ て, バイオディーゼル燃料（B100）に含まれる多不飽和 FAME の水素化を行うことで, 比較的酸化安定性が高く, 低温流動性 では多不飽和FAME に劣るものの飽和 FAME より良好な 1 価 不飽和 FAME に変換できれば, バイオディーゼル燃料の酸化 安定性の向上が期待できる ${ }^{17) 。 ~}$

そこで, 魚油混入廃食油FAMEのモデル油として，4価以上 の多不飽和 FAME を $0.95 \%$ 含有するように魚油 FAME を菜種 油FAMEに混合して魚油FAME 混合菜種油FAME を調製し, 水素化を行った。魚油 FAME, 菜種油 FAME, 魚油 FAME 混 合菜種油FAME の原料油执よび水素化処理油の各物性試験と GC-FID クロマトグラフによる組成解析結果を Table 3 に示す。 Rancimat 試験では, いずれの原料油も欧州規格（EN 14214） が定める酸化安定性の規格值を満たさなかった。多不飽和 FAME の混入が酸化安定性低下に与える影響は大きいことが分 かった。一方, 水素化した魚油FAME 混合菜種油FAMEは, 水素化処理を 2 時間行うことで大幅に酸化安定性が向上し, 規 格值を満たすことが分かった。水素化処理に伴うFAME 組成 変化から，3価以上の多不飽和 FAME は 2 時間で，また 2 価不 飽和 FAME は 5 時間でほぼ完全に水素化された。魚油 FAME 混合菜種油 FAME は Rancimat 試験時にスラッジを生成したが, 水素化処理油はスラッジ生成が見られず，水素化処理がスラッ ジ生成抑制にも有効であることが分かった。流動点は水素化処 理時間が長いほど高くなった。5時間水素化した生成油では飽 和 FAME が $76.6 \%$ と非常に多くなり，流動点は $29^{\circ} \mathrm{C}$ と大幅に 上昇し，低温流動性は悪化した。

以上の結果から, 魚油が混入したバイオディーゼル燃料 （B100）も選択的に多不飽和 FAME を水素化することにより, 魚油が混入したFAME を酸化安定性の高いニートFAMEに転 換することが可能であることが示された。

\section{4. 水素化 FAME 混合軽油の酸化安定性}

Sulfur-free 軽油（ $\mathrm{S}=6$ massppm）に魚油 FAME 混合菜種油 FAME および前節で得られた水素化処理油を 5 mass \% 混合し て B5 FAME 混合軽油を調製し，告示法によるFAME 混合軽油 酸化安定性試験を行った。結果を Table 4 に示す。各試料の全 酸価はいずれも規格值（0.13 $\mathrm{mgKOH} / \mathrm{g}$ 以下）を満たした。 FAME 混合軽油の酸化安定性の指標である全酸価増加量は, 未 処理の魚油FAME 混合菜種油FAMEを混合した軽油では, $2.61 \mathrm{mgKOH} / \mathrm{g}$ と軽油の全酸価増加量 $(0.21 \mathrm{mgKOH} / \mathrm{g})$ に比べ て大幅に増加したが，2時間水素化処理したFAMEを混合した 軽油では $0.23 \mathrm{mgKOH} / \mathrm{g}$ とほぼ軽油と同等の酸化安定性を示し た。B5の強制酸化後の全酸価増加量は $0.12 \mathrm{mgKOH} / \mathrm{g}$ 以下と規 定されているが，使用した Sulfur-free 軽油自体が酸化されたた め, 全酸価増加量は $0.12 \mathrm{mgKOH} / \mathrm{g}$ を超える值となった。本実 験では BHT 等の酸化防止剂は添加していないが, 軽油自体の 酸化は酸化防止剂の添加で改善可能である。

一方， 5 時間水素化処理したFAMEを混合した軽油では $0.05 \mathrm{mgKOH} / \mathrm{g}$ と軽油以上の酸化安定性を示した。これは, 水 素化FAME を混合することにより，軽油自体の酸化も抑制さ れたことを示しているが，その理由については検討中である。 
Table 3 Properties of Fresh and Hydrotreated Products of Rapeseed Oil FAME Blended with Fish Oil FAME

\begin{tabular}{|c|c|c|c|c|c|c|}
\hline & & \multirow{2}{*}{$\begin{array}{c}\text { Rapeseed oil } \\
\text { FAME }\end{array}$} & \multirow{2}{*}{$\begin{array}{l}\text { Fish oil } \\
\text { FAME }\end{array}$} & \multirow{2}{*}{$\begin{array}{l}\text { Rapeseed oil FAME } \\
\text { mixed with fish oil } \\
\text { FAME }^{\text {a) }}\end{array}$} & \multicolumn{2}{|c|}{ Hydrogenated blended FAME } \\
\hline & & & & & $2 \mathrm{~h}$ of hydrogenation & $5 \mathrm{~h}$ of hydrogenation \\
\hline \multicolumn{7}{|l|}{ Oxidation stability } \\
\hline Rancimat induction time & {$[\mathrm{h}]$} & 3.79 & 0.49 & 2.30 & 11.63 & $>24$ \\
\hline \multicolumn{7}{|l|}{ Water content } \\
\hline Before Rancimat oxidation process & [massppm] & 285.0 & 169.5 & 428.7 & n.a. & 250.2 \\
\hline After Rancimat oxidation process & [massppm] & 1214.3 & 754.6 & 1501.5 & n.a. & 213.4 \\
\hline \multicolumn{7}{|l|}{ Cold property } \\
\hline Cloud point & {$\left[{ }^{\circ} \mathrm{C}\right]$} & -5 & 7 & -4 & 11 & 30 \\
\hline Pour point & {$\left[{ }^{\circ} \mathrm{C}\right]$} & -12 & 0 & -10 & 9 & 29 \\
\hline \multicolumn{7}{|l|}{ Compositional analysis (GC-FID HP-88) } \\
\hline Total ester content & [area\%] & 97.86 & 89.78 & 98.78 & 98.17 & 97.39 \\
\hline Saturated FAME & [area \%] & 6.17 & 22.55 & 8.48 & 19.96 & 76.64 \\
\hline Unsaturated FAME: 1 & [area\%] & 64.28 & 39.65 & 63.14 & 73.71 & 20.40 \\
\hline cis-Unsaturated & [area\%] & 64.19 & 39.65 & 62.98 & 36.38 & 5.77 \\
\hline trans-Unsaturated & [area\%] & 0.09 & 0 & 0.16 & 37.33 & 14.63 \\
\hline Unsaturated FAME: 2 & [area\%] & 19.80 & 2.40 & 18.94 & 4.50 & 0.35 \\
\hline Unsaturated FAME: 3 & [area\%] & 7.61 & 0.77 & 7.27 & 0 & 0 \\
\hline Unsaturated FAME: $\geqq 4$ & [area\%] & 0 & 24.40 & 0.95 & 0 & 0 \\
\hline Unknown & [area\%] & 0.36 & 10.22 & 1.22 & 1.83 & 2.61 \\
\hline
\end{tabular}

a) Fish oil FAME (4.00 mass \%) + rapeseed oil FAME (96.00 mass \%).

n.a.: not analyzed.

Table 4 Cold Properties and Oxidation Stability of B5 ${ }^{\text {a) }}$

\begin{tabular}{|c|c|c|c|c|c|c|}
\hline & & \multirow{2}{*}{$\begin{array}{l}\text { B5 using } \\
\text { rapeseed oil } \\
\text { FAME }\end{array}$} & \multirow{2}{*}{$\begin{array}{c}\text { B5 using } \\
\text { rapeseed oil } \\
\text { FAME mixed } \\
\text { with fish oil } \\
\text { FAME }^{\text {b) }}\end{array}$} & \multicolumn{2}{|c|}{$\begin{array}{l}\text { B5 using hydrogenated } \\
\text { mixture FAME }\end{array}$} & \multirow{2}{*}{$\begin{array}{c}\text { Sulfur free diesel } \\
(\text { sulfur }= \\
6 \text { massppm })\end{array}$} \\
\hline & & & & $2 \mathrm{~h}$ of hydrogenation & $5 \mathrm{~h}$ of hydrogenation & \\
\hline \multicolumn{7}{|l|}{ Cold property } \\
\hline Cloud point & {$\left[{ }^{\circ} \mathrm{C}\right]$} & 0 & 0 & 0 & 1 & 0 \\
\hline Pour point & {$\left[{ }^{\circ} \mathrm{C}\right]$} & -18 & -18 & -17 & -8 & -18 \\
\hline \multicolumn{7}{|l|}{ Oxidation stability } \\
\hline Peroxide value & {$[\mathrm{meq} / \mathrm{kg}]$} & 0.61 & 0.69 & 0.16 & 0.21 & 0.24 \\
\hline Peroxide value after oxidation & {$[\mathrm{meq} / \mathrm{kg}]$} & 196.28 & 324.16 & 53.42 & 9.93 & 21.78 \\
\hline Peroxide value increase & {$[\mathrm{meq} / \mathrm{kg}]$} & 195.67 & 323.47 & 53.26 & 9.72 & 21.54 \\
\hline Total acid value & {$[\mathrm{mgKOH} / \mathrm{g}]$} & 0.01 & 0.02 & 0.02 & 0.02 & 0.01 \\
\hline Total acid value after oxidation & {$[\mathrm{mgKOH} / \mathrm{g}]$} & 0.62 & 2.63 & 0.25 & 0.07 & 0.22 \\
\hline Total acid value increase & {$[\mathrm{mgKOH} / \mathrm{g}]$} & 0.61 & 2.61 & 0.23 & 0.05 & 0.21 \\
\hline
\end{tabular}

a) B5: Blended rapeseed oil FAME (4.8 mass \%) and fish oil FAME (0.2 mass \%) with sulfur free diesel (95 mass \%).

b) Fish oil FAME (4.00 mass \%) + rapeseed oil FAME (96.00 mass \%).

自動酸化により生成した過酸化物は, 保存中に分解して酸など の開裂生成物やスラッジなどの重合物を生成することが考えら れ, 酸化劣化物質の前駆体となる。そこで, 保存安定性の指標 として過酸化物価を測定したところ, 水素化FAME 混合軽油 では過酸化物価増加量が著しく低減しており，保存安定性も向 上することが示唆された。混合軽油においても, 酸化試験時に 未処理油はスラッジを生成したが, 水素化処理油はスラッジ生 成が見られず，水素化処理が混合軽油のスラッジ生成抑制にも 有効であることが分かった。低温流動性は水素化処理を 2 時間 行ったFAMEを混合した軽油では流動点上昇が $1^{\circ} \mathrm{C}$ とわずか であったが, 過度に水素化した 5 時間水素化処理油 FAME を混 合した軽油では流動点が $10^{\circ} \mathrm{C}$ 上昇し，低温流動性が悪化した。 5 mass\% と比較的少ない混合率であっても FAME 組成の相違 が顕著に現れる結果となった。
以上の結果から, 魚油が混入したFAMEにおいても適度な 水素化処理を行うことで酸化安定性の高いバイオディーゼル燃 料を得ることが可能であることが分かった。

\section{4. 結}

魚油 FAMEの酸化試験による酸化劣化挙動の評価および水 素化処理による魚油 FAME 混合 BDF の酸化安定性改善を試み, 以下の結論を得た。

（1）魚油FAME は酸化安定性が著しく低く, 酸化により低分 子のアルデヒド類, カルボン酸と多量のスラッジを生成した。 スラッジは分子量 600 から 20,000,000の高分子化合物であった。 (2) 魚油 FAME 混合菜種油 FAME の酸化安定性は低かったが, 水素化処理を行うことで酸化安定性の向上が見られた。一方, 水素化度が高くなるに伴い飽和 FAME が増加し, 低温流動性 
が悪化するという酸化安定性の向上とのトレードオフの関係が みられたため, 水素化度の適正化が必要である。

（3）魚油が混合されたFAMEであっても適切な水素化処理を 行うことにより，B5 FAME 混合軽油とした場合の酸化安定性 を著しく改善できることが確認された。

\section{謝 辞}

本研究を行うに際して Sulfur-free 軽油のご提供をいただいた (独) 産業技術総合研究所の後藤新一博士ほか関係者各位に謝意 を表します。また，本研究で使用した粗製魚油のご提供をいた だいた日本化学飼料(株)に謝意を表します。

\section{References}

1) Bozbas, K., Renew. Sust. Energ. Rev., 12, (2), 546 (2008).

2) http://www. hkd. meti. go. jp/hokno/kihatsuyu/shiryou01. pdf. 経済産業省, 揮発油等の品質の確保等に関する法律施行 規則の一部を改正する省令, (2009).

3) Korbiz, W., Renewable Energy, 16, (1-4), 1078 (1999).

4) Sarin, R., Sharma, M., Shinharay, S., Malhotra, R. K., Fuel, 86, (10-11), 1365 (2007).

5) http://www. env. go. jp/recycle/report/h19-01/chpt4-3. pdf. 環境省, “一般廃棄物に係る新基準策定調査報告書, ”
(2006).

6) Sioen, I., Haak, L., Raes, K., Hermans, C., De Henauw, S., De Smet, S., Van Camp, J., Food Chem., 98, (4), 609 (2006).

7) Meber, J., Bochi, V. C., Ribeiro, C. P., Victorio, A. D., Emanuelli, T., Food Chem., 106, (1), 140 (2008).

8) Bouaid, A., Maetinez, M., Aracil, J., Fuel, 86, (16), 2596 (2007).

9) http://www. meti. go. jp/committee/materials/downloadfiles/ g60428b04j. pdf.

総合資源エネルギー調査会石油分科会石油部会燃料政策 小委員会企画検討ワーキンググループ配布資料, (2006).

10) Moser, B. R., Haas, M. J., Winkler, J. K., Jackson, M. A., Erhan, S. Z., List, G. R., Eur. J. Lipid Sci. Technol., 109, (1), 17 (2007).

11) Fork, O., Eur. J. Lipid. Technol., 106, (12), 837 (2004).

12) Boocock, Brooke, D. G., U. S. Pat. 6712867 (2004).

13) http://www. enecho. meti. go. jp/info/event/data/070323a-5. pdf. 経済産業省，経済産業省告示第八十一号, (2007).

14) Abdulkarim, S. M., Long, K., Lai, O. M., Muhammad, S. K. S., Ghazali, H. M., Food Chem., 105, (4), 1384 (2007).

15) http: //www. biomass-hq. jp/tech/index_explanation. html. (財) 政策科学研究所, “地方自治体におけるバイオディー ゼル燃料の規格化と利用に関する調査,” (2006).

16) Gunstone, F. D., J. Am. Oil. Chem. Soc., 61, (2), 441 (1984).

17) Beckmann, H. J., J. Am. Oil. Chem. Soc., 60, (2), 282 (1983).

\title{
要 旨
}

\section{魚油バイオディーゼルに含まれる脂肪酸メチルエステルの酸化挙動および部分水素化処理による酸化安定性の改善}

\author{
阿部 容子, 鳥羽 誠, 望月 剛久, 臀村 雄二
}

(独) 産業技術総合研究所 新燃料自動車技術研究センター, 305-8565 茨城県つくば市東1-1-1

魚油が混入した廃食用油利用の観点から，まず魚油脂肪酸メ チルエステル（FAME）の酸化劣化による変化を評価し，次い で貴金属触媒を用いて部分水素化した魚油 FAME の酸化安定 性について検討を行った。魚油 FAMEは酸化によりアルデヒ ド類，カルボン酸類，ケトン類および大量のスラッジなど多種 の分解生成物を生じた。FAMEの酸化反応性はその不飽和度に 比例し，魚油 FAMEの主成分である4価以上の二重結合を有す る多不飽和 FAME はほぼ完全に酸化された。元素分析や FT-IR の結果から, スラッジはケトン類, エステル類およびカルボン 酸類による大量の酸素を含有していることが分かった。ゲル浸 透クロマトグラフにより測定した数平均分子量から，スラッジ は多不飽和 FAME を主とした抢よそ10分子のFAMEの重合に
より形成していると考えた。バイオディーゼル燃料に混入した 魚油の酸化安定性を改善するために, $\mathrm{Pd}-\mathrm{Pt} / \mathrm{Yb}-\mathrm{USY}-\mathrm{Al}_{2} \mathrm{O}_{3}$ 触 媒を使用して魚油FAME を部分水素化した。ここでは, 魚油 混合廃食用油のモデル油とするため, 魚油FAMEを菜種油 FAME に混合したものを水素化原料とした。2 価以上の不飽和 FAME は 1 価不飽和 FAME および飽和 FAMEへと選択的に水 素化された。水素化 FAME は酸化によりスラッジを生成せず, 酸化安定性は未処理油と比較して大幅に向上した。水素化 FAME 混合軽油の酸化安定性は石油系軽油とほぼ同等であっ た。多不飽和 FAME の部分的水素化は酸化安定性向上とスラッ ジ形成の抑制に効果的であることが分かった。 